\title{
The development of sexual differences in body size in Odonata in relation to mating systems
}

\author{
Martin-Alejandro SERRANO-MENESES ${ }^{1}$, Mónica AZPILICUETA-AMORÍN ${ }^{2}$, TAMÁs SZÉKELY ${ }^{1}$ and \\ ALEX CÓRDOBA-AGUILAR ${ }^{3}$
}

\author{
${ }^{1}$ Department of Biology and Biochemistry, University of Bath, Claverton Down, Bath BA2 7AY, UK; \\ e-mail: mserrano@miranda.ecologia.unam.mx \\ ${ }^{2}$ Grupo de Ecoloxía Evolutiva e da Conservación, Departamento de Ecoloxía e Bioloxía Animal, Universidade de Vigo, E.U.E.T. \\ Forestal, Campus Universitario, 36005 Pontevedra, Galicia, Spain \\ ${ }^{3}$ Departamento de Ecología Evolutiva, Instituto de Ecología, Universidad Nacional Autónoma de México, Apdo. Postal 70-275, \\ C. P. 04510, México, D.F., México
} Key words. Odonata, Anisoptera, Anax imperator, Cordulegaster boltonii, Onychogomphus uncatus, Oxygastra curtisii, Zygoptera,
Cercion lindeni, Ischnura graellsii, Platycnemis acutipennis, sexual size dimorphism

\begin{abstract}
Adult body size is the result of important environmental, maternal and/or genetic effects acting on animals during development. Here we investigate how sexual size dimorphism (SSD) develops in seven species of Odonata: Anax imperator, Cordulegaster boltonii, Onychogomphus uncatus, Oxygastra curtisii (Anisoptera), Cercion lindeni, Ischnura graellsii and Platycnemis acutipennis (Zygoptera). SSD of both the last larval and adult stages of the same individuals, which were reared under laboratory conditions, was measured. The aims were to investigate (i) whether SSD develops during the larval stage, (ii) the direction of larval and adult SSD, and (iii) whether the direction of adult SSD can be predicted by the mating system of a given species (e.g. males of territorial species being larger than females and the opposite for non-territorial species). We found that although larval differences in size may be present between the sexes, these are not necessarily shown in the adult stage (they may change or disappear). Also, the mating system was not related to patterns of adult SSD. Differences in SSD in larvae may be caused by differential use of resources via differential niche-utilisation or sex-specific growth patterns. We highlight the fact that sexual selection favouring large male size and fecundity selection, which selects for large females may be acting on the observed patterns in SSD in adults.
\end{abstract}

\section{INTRODUCTION}

Differences in body size between males and females are common in many animals (Andersson, 1994). For instance, in many invertebrate species, sexually mature females are several times larger than males (femalebiased SSD), whereas in most mammals and birds, males are the larger sex (male-biased SSD; Abouheif \& Fairbairn, 1997; Blanckenhorn, 2005; Székely et al., 2007). Three functional hypotheses are usually advanced to explain the degree and direction of SSD exhibited by a given species or higher taxon: (i) fecundity selection acting on female body size usually produces femalebiased SSD through increasing fecundity with female size (Honěk, 1993; Head, 1995; Prenter et al., 1999), (ii) differential niche utilisation between males and females reducing the competition for resources between the sexes and promoting morphological divergence (Selander, 1966; Shine, 1989; Thom et al., 2004) and (iii) sexual selection favouring male-biased SSD in species in which males compete for females on the ground (Anderson \& Fedak, 1985; Lindenfors \& Tullberg, 1998; SerranoMeneses \& Székely, 2006), or female-biased SSD in species in which males compete in the air (Andersson \& Norberg, 1981; Raihani et al., 2006; Serrano-Meneses \& Székely, 2006).
Studies often approach SSD from a functional perspective to investigate the ecological and/or behavioural causes and consequences of SSD in adults (see Blanckenhorn, 2005). However, the observed patterns of SSD in the adult stage are the result of important differences in physiology, behaviour and in the ecological niches occupied by the sexes during growth and development (Le Gaillard et al., 2006). These differential factors may produce divergent selective pressures on the ontogeny of males and females (e.g. developmental time, size at hatching or growth rate) leading to SSD in adults (Badyaev, 2002). Thus, adult body size may be genetically fixed (e.g. queen size in the ant Leptothorax rugatulus; Rüppell et al., 2001), or influenced by environmental factors, such as the amount of food available during the early stages of development (e.g. male body size in the horned beetle Onthophagus taurus; Emlen \& Nijhout, 2001). Note, that although the long-term evolution of SSD is to an extent constrained by genetic factors (Reeve \& Fairbairn, 1996), ecological or behavioural pressures can drive the evolution of SSD even in presence of strong genetic correlation between the sexes (Badyaev, 2002).

Differences in adult body size develop in one of two ways: organisms may grow at a faster rate or for a longer period (Blanckenhorn, 2005). Therefore, differences in adult body size between the sexes are likely to arise if the sexes differ in developmental time and/or growth rate. In 
TABLE 1. Locations and dates of collections. Mating system denotes territorial (T) or non-territorial (NT) species. Initial $n$ is the number of larvae collected of a given species (the number of emerged adults differs due to mortality). Rearing duration refers to the period in days from the day when the larvae were captured until the adults emerged.

\begin{tabular}{|c|c|c|c|c|c|c|}
\hline Species & $\begin{array}{l}\text { Mating } \\
\text { system }\end{array}$ & Site & Coordinate & $\begin{array}{l}\text { Date of } \\
\text { collection }\end{array}$ & $\begin{array}{c}\text { Rearing } \\
\text { duration in days }\end{array}$ & Initial $n$ \\
\hline \multicolumn{7}{|l|}{ ANISOPTERA } \\
\hline Anax imperator & $\mathrm{T}$ & Marcosende & $42^{\circ} 4^{\prime} 4^{\prime \prime} \mathrm{N}, 8^{\circ} 40^{\prime} 4^{\prime \prime} \mathrm{W}$ & 12-May-06 & 48 & $\begin{array}{l}30 \text { ô } \\
30 \text { क }\end{array}$ \\
\hline Cordulegaster boltonii & $\mathrm{T}$ & Covelo & $42^{\circ} 23^{\prime} 10^{\prime \prime} \mathrm{N}, 8^{\circ} 3^{\prime} 20^{\prime \prime} \mathrm{W}$ & 29-Apr-06 & 50 & $\begin{array}{l}30 \text { ठ } \\
30 \text { }\end{array}$ \\
\hline Onychogomphus uncatus & $\mathrm{T}$ & Covelo & $42^{\circ} 23^{\prime} 10^{\prime \prime} \mathrm{N}, 8^{\circ} 31^{\prime} 20^{\prime \prime} \mathrm{W}$ & 29-Apr-06 & 18 & $\begin{array}{l}30 \text { ठ } \\
30 \stackrel{9}{0}\end{array}$ \\
\hline Oxygastra curtisii & $\mathrm{T}$ & Covelo & $42^{\circ} 23^{\prime} 10^{\prime \prime} \mathrm{N}, 8^{\circ} 31^{\prime} 20^{\prime \prime} \mathrm{W}$ & 29-Apr-06 & 31 & $\begin{array}{l}30 \text { ○ } \\
30 \text { }\end{array}$ \\
\hline \multicolumn{7}{|l|}{ ZYGOPTERA } \\
\hline Cercion lindeni & $\mathrm{T}$ & Marcosende & $42^{\circ} 4^{\prime} 4^{\prime \prime} \mathrm{N}, 8^{\circ} 40^{\prime} 4^{\prime \prime} \mathrm{W}$ & 12-May-06 & 18 & 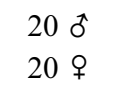 \\
\hline Ischnura graellsii & NT & Lourizán & $42^{\circ} 25^{\prime} 24^{\prime \prime} \mathrm{N}, 8^{\circ} 40^{\prime} 40^{\prime \prime} \mathrm{W}$ & 25-May-06 & 50 & $\begin{array}{l}35 \text { t } \\
35 \text { }\end{array}$ \\
\hline Platycnemis acutipennis & NT & Tenorio & $42^{\circ} 28^{\prime} 50^{\prime \prime} \mathrm{N}, 8^{\circ} 37^{\prime} 40^{\prime \prime} \mathrm{W}$ & 05-Nov-05 & 67 & $\begin{array}{l}20 \text { ठ } \\
20 \text { ? }\end{array}$ \\
\hline
\end{tabular}

many insects, such as odonates, these ontogenic factors are not entirely determined genetically, but are likely to fluctuate with changes in environmental conditions such as temperature, time in the reproductive season and food availability (Corbet, 1999). Food, in particular, is a limiting resource for accruing maximum fitness benefits in both sexes. For example, territorial male dragonflies that receive a highly nutritious diet during development are bigger, and have greater muscle mass and fat reserves at emergence (Plaistow \& Siva-Jothy, 1999). These traits are related to male-male competition for mating territories since individuals with large fat reserves are more successful during aggressive territorial contests (Marden \& Waage, 1990; Plaistow \& Tsubaki, 2000; SerranoMeneses et al., in press). A recent study in Hetaerina americana shows that fat reserves increase with body size in territorial individuals (Serrano-Meneses et al., 2007), suggesting that large size is selectively advantageous to males of territorial species. Since territorial males often gain more matings than non-territorial individuals (e.g. Waage, 1973; Grether, 1996; Córdoba-Aguilar, 2000), the former obtain higher paternity benefits compared to the latter. Therefore, territory defence may favour large male size, potentially resulting in male-biased SSD. Females, on the other hand, gain fitness benefits such as enhanced survival at emergence (Braune \& Rolff, 2001) and higher fecundity via large size (Cordero-Rivera, 1991). Fecundity selection, therefore, will favour large female body size (e.g. Honěk, 1993).

The order Odonata is an example of a taxon with marked differences in SSD. Several species have been intensively studied in terms of sexual behaviour and, broadly speaking, two mating systems have been clearly outlined: territorial and non-territorial species (Corbet, 1999). In the former, males usually gather at aquatic sites defending a place against male conspecifics, where females arrive to mate and lay eggs (e.g. Waage, 1973). In the latter, males do not defend territories but search for females in a manner similar to scramble competition (e.g. Fincke, 1985). These two mating system should be correlated with different ranges of SSD (for a study supporting this claim see Johansson et al., 2005): in territorial species, males should be the larger sex, while in nonterritorial species, this prediction would not hold as fecundity selection pressure may result in similar sizes and/or female biased SSD. Nevertheless, to the best of our knowledge, how these differences arise during development has scarcely been studied (e.g. Mikolajewski et al., 2005).

Here we investigate the development of SSD in five territorial and two non-territorial odonate species (Anisoptera and Zygoptera). First, whether SSD develops during the larval stage or after emergence was investigated. This, to the best of our knowledge, has not been investigated in this insect order. Therefore, SSD both at the last larval and the adult stage measured on the same individuals, reared in the laboratory, was recorded. Second, whether SSD in adults is correlated with SSD of the last larval stage prior to adult emergence is investigated. The investigation of the patterns of SSD in both larvae and adults can improve our understanding of the selective processes that act on the sizes of males and females. Finally, whether adult SSD can be predicted by the mating system of a given species was investigated: territorial species should exhibit male-biased SSD whereas non-territorial species should exhibit female-biased SSD.

\section{METHODS}

\section{Larvae}

The larvae of seven species (Anisoptera: Anax imperator, Cordulegaster boltonii, Onychogomphus uncatus, Oxygastra curtisii; Zygoptera: Cercion lindeni, Ischnura graellsii, Platycnemis acutipennis) were collected at 4 sites in the province of 
Pontevedra, North-West Spain (see Table 1 for mating systems, dates and collection sites). These species were chosen since their biology is well known (Corbet, 1999) and they are commonly found throughout North-West Spain. Since we were interested in the extent and direction of SSD at the last larval stage (F0 henceforward) and at adulthood, we only collected those larvae from which it was presumed adults were about to emerge. At collection, the larvae were sexed based on whether they had or lacked an ovipositor. All larvae collected on a given day were stored in one container with water and vegetation from the river (the vegetation was used by the larvae as a substrate). The larvae were determined in the field using the taxonomic key of Gerken \& Sternberg (1999). The larvae were then transported to the laboratory at the University of Vigo within one hour of collection. Before assigning the larvae to individual rearing containers, the body length of every larva was measured (from the tip of the head to the end of the abdomen, excluding the gills in the case of zygopterans) using a digital calliper (LCD electronic digital Vernier calliper; measurements made to the nearest 0.001 $\mathrm{mm})$. Larvae in F0 stadium were identified by the advanced development of their wing sheaths and eye index (Corbet, 1999), and larvae in other stadia were returned to their natural habitat (see Table 1).

After measurement, all larvae were placed individually in labelled plastic containers with a wooden stick to allow perching and a volume of water that filled approximately $2.5-3.5 \mathrm{~cm}$ of container for zygopterans and anisopterans, respectively. Each container was then covered with a plastic net to prevent emerging individuals from escaping. Water was replaced by fresh water every day. Zygopterans were fed daily 1 worm (either Tubifex tubifex or Lumbriculus variegatus), while anisopterans were fed 2 worms (Van Gossum et al., 2003). The diet for each species and sex was such that no individual was fed on a single species of worm: zygopterans were fed every day with a different worm and anisopterans were fed daily one worm of each species.

Emerging tenerals were placed in individual insectaries of approximately $60 \mathrm{~cm} \times 50 \mathrm{~cm} \times 50 \mathrm{~cm}$. Inside each insectary eight wooden sticks were provided for perching, and a water container, covered with a plastic net, to maintain humidity. The natural photoperiod of the appropriate season was maintained (approximately $12 \mathrm{~h}$ ) by illuminating the insectary with a commercially available light bulb. Each individual was kept for approximately $24 \mathrm{~h}$ in an insectary until its exoskeleton had fully hardened, and then their body length was measured using a digital calliper. After this, the adults were either released at the location of their capture, or the species that emerged during winter ( $P$. acutipennis), which were not likely to survive in nature, were stored in absolute ethanol.
Body length was used as a proxy for body size for two reasons. First, other measurements, such as wing length and head width are positively correlated with body length in odonates (M.A. Serrano-Meneses, unpubl.). Second, estimating SSD from differences in body mass may not be reliable since it is known to fluctuate with age and condition (Anholt et al., 1991).

\section{Statistical analyses}

Only those individuals that survived until emergence were included in the analyses. The data on body size were normally distributed; therefore it was not necessary to transform the data prior to analyses. To analyse the change in body size of each species we used mixed-model ANOVA: body size was the dependent variable, developmental stage (F0, adult) was the within-subject factor and sex (male, female) was the betweensubject factor. We also included the interaction term stage ${ }^{*}$ sex in the models.

To compare the changes in SSD in the two stages and between sub-orders, the SSD for larvae $\left(\mathrm{SSD}_{\mathrm{F} 0}\right)$ and adults $\left(\mathrm{SSD}_{\text {adult }}\right)$ were first calculated separately as $\log _{10}$ (male size) $\log _{10}$ (female size) (Smith, 1999), and then $\mathrm{SSD}_{\text {delta }}=\mathrm{SSD}_{\text {adult }}$ $\mathrm{SSD}_{\mathrm{F} 0}$. A positive $\mathrm{SSD}_{\text {delta }}$ indicates a shift toward male-biased $\mathrm{SSD}$, whereas a negative $\mathrm{SSD}_{\text {delta }}$ indicates a shift toward female-biased SSD.

Statistical analyses were carried out using SPSS Ver. 14. Results are provided as mean \pm S.D.

\section{RESULTS}

\section{Anisoptera}

Two out of the four territorial species exhibited femalebiased SSD at F0 (A. imperator, C. boltonii; Table 2, Fig. $1 \mathrm{~A})$ and two species were monomorphic at the same stage (O. uncatus, O. curtisii). All but one species (O. curtisii) exhibited female-biased SSD at the adult stage (Table 2, Fig. 1A). A statistically significant interaction between stage and sex indicated that the magnitude of SSD changed from F0 to adults in C. boltonii and O. uncatus (Tables 2 and 3).

\section{Zygoptera}

In the territorial species, C. lindeni, adult male-biased SSD was apparent in the larval stage. In the other two non-territorial species, adults were monomorphic, whereas in the larval stage one species showed femalebiased SSD (P. acutipennis) and I. graellsii exhibited no SSD in either the adult or F0 stages (Table 2, Fig. 1B). A statistically significant interaction between stage and sex

TABLE 2. Mixed model ANOVAs of body length (response variable) in relation to stage (within-subjects factor; F0, adult) and sex (between-subjects factor; male, female). A separate model was built for each species.

\begin{tabular}{lccccccc}
\hline \multirow{2}{*}{ Species } & \multirow{2}{*}{ Error d.f. } & \multicolumn{2}{c}{ Stage } & \multicolumn{3}{c}{ Sex } & \multicolumn{2}{c}{ Stage * sex } \\
\cline { 3 - 8 } & & $F$ & $P$ & $F$ & $P$ & $F$ & $P$ \\
\hline ANISOPTERA & & & & & & & \\
$\quad$ Anax imperator & 17 & 872.893 & 0.001 & 19.509 & 0.001 & 4.103 & 0.059 \\
$\quad$ Cordulegaster boltonii & 18 & 13745.35 & 0.001 & 557.615 & 0.001 & 435.321 & 0.001 \\
$\quad$ Onychogomphus uncatus & 18 & 5758.845 & 0.001 & 8.054 & 0.011 & 26.123 & 0.001 \\
$\quad$ Oxygastra curtisii & 19 & 4029.65 & 0.001 & 0.203 & 0.657 & 0.056 & 0.816 \\
ZYGOPTERA & & & & & & & \\
Cercion lindeni & 22 & 7215.418 & 0.001 & 10.381 & 0.004 & 5.657 & 0.026 \\
Ischnura graellsii & 24 & 1418.217 & 0.001 & 0.066 & 0.799 & 1.340 & 0.259 \\
Platycnemis acutipennis & 22 & 9357.662 & 0.001 & 0.012 & 0.913 & 12.529 & 0.002 \\
\hline
\end{tabular}



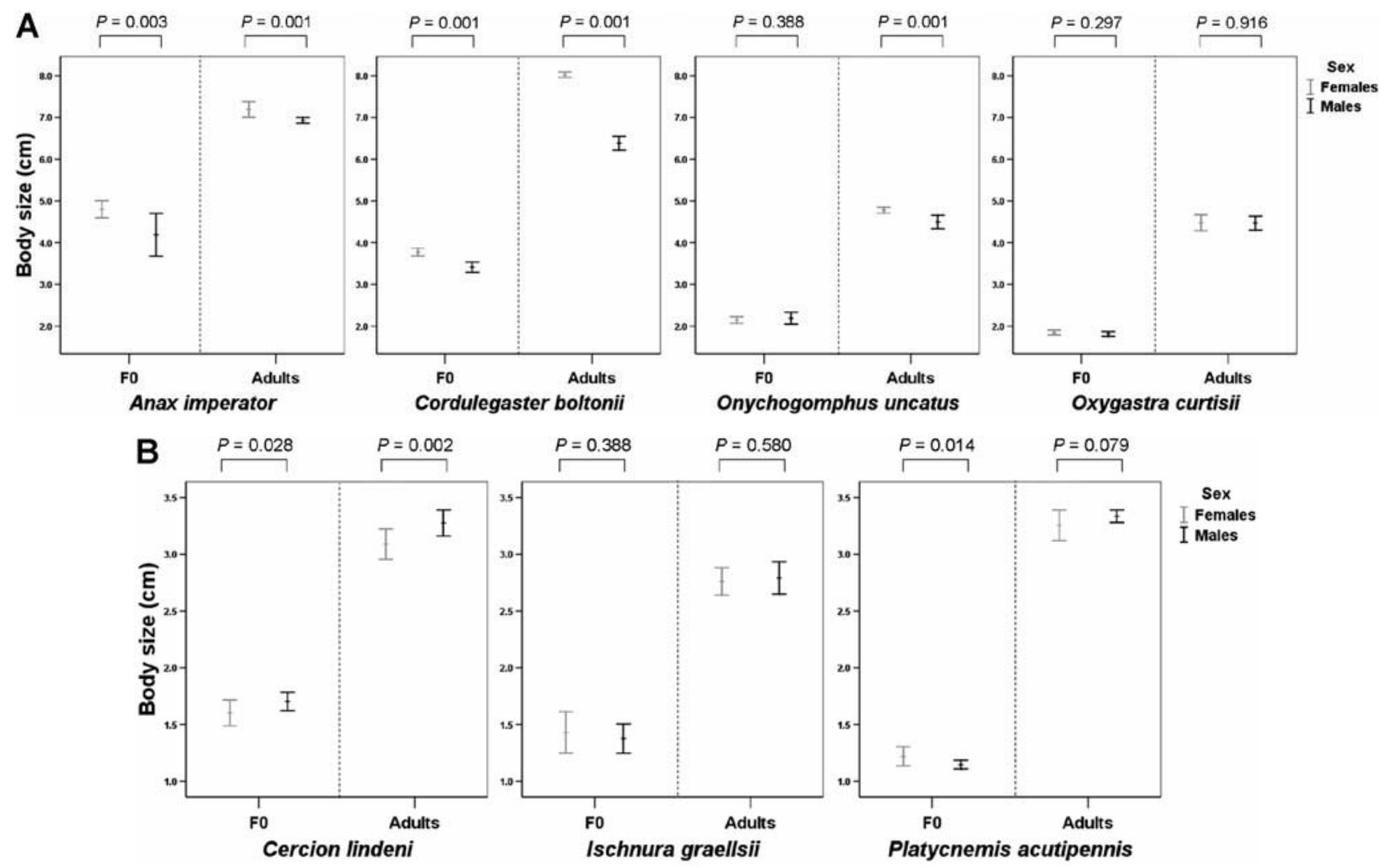

Fig. 1. Body length of F0 larvae and adults in (A) Anisoptera and (B) Zygoptera (means \pm S.D.). $P$ indicates the probability of two-sample $t$-tests.

indicated that the magnitude of SSD changed from F0 to adults in $C$. lindeni and $P$. acutipennis (Tables 2 and 3 ).

\section{DISCUSSION}

SSD was observed in four out of the seven species examined. In three species, significant differences in adult body size between the sexes were already present in the larval stage, in two species both larvae and adults did not exhibit SSD, in one species SSD only developed after emergence and in one species the pattern of SSD observed in the larval stage shifted after emergence. These results do not support the idea that the size differences observed in the adult stage are similar to those exhibited by larvae. This is corroborated by the lack of clear predictable SSD patterns in larvae that can be translated to the adult stages.
We predicted that territorial species should exhibit male-biased SSD because of strong sexual selection acting on males. This is expected since large male body size is usually favoured in male-male competition (see Blanckenhorn, 2005). In this type of competition, muscle mass and fat reserves are positively selected for in damselflies (e.g. Marden \& Waage, 1990; Plaistow \& SivaJothy, 1999; Plaistow \& Tsubaki, 2000; Serrano-Meneses et al., in press), and provide an explanation for why large body size is usually advantageous for territorial males. However, in the absence of strong male-male competition (e.g. non-territorial species) strong fecundity selection may favour large female body size, resulting in monomorphism or female-biased SSD. In our study, with the exception of one species (C. lindeni), adult males were not larger than females in territorial species. In fact, in three territorial anisopterans, females were significantly

TABLE 3. SSD in odonate larvae (F0 stage) and adults. $>$ and $<$ indicate statistically significant differences in size between the sexes, whereas = indicates a non-significant difference. In brackets is the $\mathrm{SSD}_{\text {delta }}$ (see Methods). A positive $\mathrm{SSD}_{\text {delta }}$ indicates a shift toward male-biased SSD, whereas a negative SSD $_{\text {detta }}$ indicates a shift toward female-biased SSD. T and NT indicate whether the species is territorial or non-territorial, respectively.

\begin{tabular}{|c|c|c|c|c|}
\hline & & \multicolumn{3}{|c|}{ SSD in adults } \\
\hline & & Males $>$ Females & Males $=$ Females & Males $<$ Females \\
\hline \multirow{3}{*}{$\begin{array}{l}\text { SSD } \\
\text { in F0 }\end{array}$} & $\begin{array}{l}\text { Males }> \\
\text { Females }\end{array}$ & Cercion lindeni $(-0.001, \mathrm{~T})$ & & \\
\hline & $\begin{array}{l}\text { Males }= \\
\text { Females }\end{array}$ & & $\begin{array}{c}\text { Ischnura graellsii }(0.046, \mathrm{NT}) \\
\text { Oxygastra curtisii }(0.006, \mathrm{~T})\end{array}$ & Onychogomphus uncatus $(-0.036, \mathrm{~T})$ \\
\hline & $\begin{array}{l}\text { Males }< \\
\text { Females }\end{array}$ & & Platycnemis acutipennis $(-0.056, \mathrm{NT})$ & $\begin{array}{l}\text { Cordulegaster boltonii }(-0.056, \mathrm{~T}) \\
\text { Anax imperator }(0.046, \mathrm{~T})\end{array}$ \\
\hline
\end{tabular}


larger than males at this stage. In two of these species, this difference was in fact already present in the larval stage. There may be two explanations for these findings. The first is that differences in the type of male-male competition and territory defence in anisoptera and zygoptera favour different male sizes. Firstly, it is possible that territorial anisopterans benefit from small, more manoeuvrable sizes since most of the territorial defence and reproductive-related activities occur in the air (Corbet, 1999). This would favour monomorphism or femalebiased SSD in territorial anisopterans. Secondly, large size may be more advantageous to territorial male zygopterans because it enhances territory defence (e.g. through increased energy storage; Serrano-Meneses et al., 2007). This scenario favours male-biased SSD in territorial zygopterans. The second explanation is that despite being territorial, males are not larger than females for reasons related to the advantages that females gain from large body size, such as an increase in fecundity (e.g. Honěk, 1993). Fecundity selection acting on female body size may be strong in those species in which females are the larger sex, including the only territorial species that did not exhibit adult SSD $(O$. curtisii).

In the two non-territorial species (P. acutipennis and $I$. graellsii) no significant SSD was found. This is consistent with the expected pattern since large male size should be less advantageous in scramble competition (e.g. Anholt et al., 1991). Male-male scramble competition in non-territorial species, therefore, is expected to favour monomorphism or female-biased SSD (Anholt et al., 1991; see also Fincke et al., 1997).

In this study, some species exhibited SSD during the larval stage whereas others did not. Why do some species show SSD during the larval stage? One explanation is that ecological differences between the sexes may favour different male and female body sizes prior to emergence. Nevertheless, we know of no evidence that suggests differences in larval habitat of the sexes. Although some form of territoriality (which includes aggressive behaviour) is reported in the larval stage of several odonates (e.g. Rowe, 2004), it is unknown whether this behaviour is sex-specific. Another explanation is that these species may exhibit sex-specific developmental times, so that one sex may develop for longer and achieve a larger size (e.g. Badyaev, 2002). Recent evidence in Ischnura elegans, for example, indicate that males develop faster and consequently, emerge at smaller sizes than females, presumably a consequence of scramble competition (Abbot \& Svensson, 2005; for a similar result also see Mikolajewski et al., 2005). This may mean that it is advantageous for males to emerge earlier in the season in order to search for females. This mechanistic explanation may apply to territorial and non-territorial species, favouring sexspecific differences in the larval stage (e.g. Badyaev, 2002) and provides an explanation for our results. Another recent study on nine libelullids, which included territorial and non-territorial species, did not show sexual differences in egg size (Schenk \& Söndgerath, 2005). This suggests that SSD in Odonata is not a consequence of differences in egg size but develops during larval development. Mikolajewski et al. (2005) for example, recorded that Coenagrion puella males show greater activity than females in the larval stage (for no differences in activity between the sexes, see Stoks, 1999). In this non-territorial species and in the same study, females were larger and heavier than males at emergence. This pattern of sexual differences is similar to that recorded here for $P$. acutipennis, which is also a non-territorial species. Why do some other species do not exhibit SSD during the larval stage? The lack of larval SSD in some of the species studied here may be the result of viability selection acting strongly on the sizes of both males and females (Blanckenhorn, 2005). Viability selection is therefore expected to select for small size in both sexes, if large size increases mortality rates (e.g. through increased predation or starvation; Blanckenhorn, 2005). This can favour similar sizes in both males and females prior to emergence (e.g. Blanckenhorn, 2000).

Taken together, our results show that SSD is likely to arise during the larval stage in certain species, arise only after emergence, and be exhibited in the larval stage and then disappear in the adult stage in other species. Mating systems were not good predictors of the direction of SSD (e.g. territorial species did not exhibit male-biased SSD); nevertheless, one has to be careful before drawing conclusions from these results because our study has a number of limitations. For instance, the comparative power of the SSD territorial vs. the SSD of non-territorial species is low due to: (i) small sample size, (ii) the distribution of territorial and non-territorial species (four out of seven species were territorial anisopterans, one territorial species was a zygopteran and the two non-territorial species were zygopterans) and (iii) we did not control for the phylogenetic non-independence of species (see Harvey \& Pagel, 1991). Future studies should make use of the advances in the understanding of the phylogenetic relationships of odonates (e.g. Misof et al., 2001; Rehn, 2003; Dumont et al., 2005), which along with the unique diversity of SSD in this insect group (e.g. Anholt et al., 1991; Andersson, 1994), provide an excellent opportunity to test and understand the selective processes that shape SSD in animals.

ACKNOWLEDGEMENTS. We would like to extend our gratitude to the laboratory of the Grupo de Ecoloxía Evolutiva e da Conservación, Departamento de Ecoloxía e Bioloxía Animal, Universidade de Vigo and especially to A. Cordero-Rivera for providing us with the space and materials to further our investigation. M.A. S.-M. was funded by CONACyT, Mexico (Registro de Beca 168893).

\section{REFERENCES}

Аввот J. \& Svensson I. 2005: Phenotypic and genetic variation in emergence and development time of a trimorphic damselfly. J. Evolution. Biol. 18: 1464-1470.

ABouheIF E. \& FAIRBAIRn D.J. 1997: A comparative analysis of allometry for sexual size dimorphism: assessing Rensch's Rule. Am. Nat. 149: 540-562.

Anderson S.S. \& FedAK M.F. 1985: Grey seal males: Energetic and behavioural links between size and sexual success. Anim. Behav. 33: 829-838. 
Andersson M. 1994: Sexual Selection. Princeton University Press, Princeton, New Jersey, 599 pp.

ANDERsSON M. \& Norberg R.A. 1981: Evolution of reversed sexual size dimorphism and role partitioning among raptors, with a size scaling of flight performance. Biol. J. Linn. Soc. 15: $105-130$.

Anholt B.R., Marden J.H. \& Jenkins D.M. 1991: Patterns of mass gain and sexual dimorphism in adult dragonflies (Insecta: Odonata). Can. J. Zool. 69: 1156-1163.

BADYAEV A. 2002: Growing apart: an ontogenic perspective on the evolution of sexual size dimorphism. Trends Ecol. Evol. 17: $369-378$

BLANCKENHORN W.U. 2005: Behavioral causes and consequences of sexual size dimorphism. Ethology 111: 977-1016.

Braune P. \& RolfF J. 2001: Parasitism and survival in a damselfly: does host sex matter? Proc. R. Soc. Lond. (B) 268: $1133-1137$.

Corbet P.S. 1999: Dragonflies: Behaviour and Ecology of Odonata. Harley Books, Clochester, 829 pp.

Cordero-Rivera A. 1991: Fecundity of Ischnura graellsii (Rambur) in the laboratory (Zygoptera: Coenagrionidae). Odonatologica 20: 37-44.

Córdoba-Aguilar A. 2000: Reproductive behaviour in the territorial damselfly Calopteryx haemorrhoidalis asturica Ocharan (Zygoptera: Calopterygidae). Odonatologica 29: 297-307.

Dumont H.J., Vlanfeteren J.R., De JonckHeere J.F. \& Weekers P.H.H. 2005: Phylogenetic relationships, divergence time estimation, and global biogeographic patterns of Calopterygoid damselflies (Odonata, Zygoptera) inferred from ribosomal DNA sequences. Syst. Biol. 54: 347-362.

EMLEN D.J. \& NiJHout H.F. 2001: Hormonal control of male horn length dimorphism in Onthophagus taurus (Coleoptera: Scarabaeidae): a second critical period of sensitivity to juvenile hormone. J. Insect Physiol. 47: 1045-1054.

FinCKE O.M. 1985: Alternative mate-finding tactics in a nonterritorial damselfly (Odonata: Coenagrionidae). Anim. Behav. 33: 1124-1137.

FincKe O.M., Waage J.K. \& Koenig W. 1997: Natural and sexual selection components of odonate mating patterns. In Choe J.C. \& Crespi B.J. (eds): Mating Systems in Insects and Arachnids. Cambridge University Press, Cambridge, pp. 58-74.

GRETHER G.F. 1996: Sexual selection and survival selection on wing coloration and body size in the Rubyspot damselfly Hetaerina americana. Evolution 50: 1939-1948.

Gerken B. \& Sternberg K. 1999: Die Exuvien europäischer Libellen (Insecta, Odonata). Arnika \& Eisvogel, Höxter \& Jena, $354 \mathrm{pp}$.

Harvey P. \& Pagel M.D. 1991: The Comparative Method in Evolutionary Biology. Oxford University Press, Oxford, 239 pp.

HEAD G. 1995: Selection on fecundity and variation in the degree of sexual size dimorphism among spider species (Class Araneae). Evolution 49: 776-781.

HoNĚK A. 1993: Intraspecific variation in body size and fecundity in insects: A general relationship. Oikos 66: 483-492.

Johansson F., Crowley P.H. \& Brodin T. 2005: Sexual size dimorphism and sex ratios in dragonflies (Odonata). Biol. $J$. Linn. Soc. 86: 507-513.

Le Gaillard J.-F., Massot M., Landys M.M., Meylan S. \& Clobert J. 2006: Ontogenic causes of variation in sexual size dimorphism in a viviparous lizard. J. Evolution. Biol. 19: 690-704.

Lindenfors P. \& Tullberg B.S. 1998: Phylogenetic analyses of primate size evolution: the consequences of sexual selection. Biol. J. Linn. Soc. 64: 413-447.

MARDEN J.H. \& WAAKE J.K. 1990: Escalated territorial contests are energetic wars of attrition. Anim. Behav. 39: 954-959.
Mikolajewski D.J., Brodin T., Johansson F. \& Joop G. 2005: Phenotypic plasticity in gender specific life-history: effects of food availability and predation. Oikos 110: 91-100.

Misof B., Rickert A.M., Buckely T.R., Fleck G. \& Sauer K.P. 2001: Phylogenetic signal and its decay in mitochondrial SSU and LSU rRNA gene fragments of Anisoptera. Mol. Biol. Evol. 18: 27-37.

Plaistow S.J. \& Siva-Jothy M. 1999: The ontogenetic switch between odonate life history stages: effects on fitness when time and food are limited. Anim. Behav. 58: 659-667.

Plaistow S.J. \& Tsubaki Y. 2000: A selective trade-off for territoriality and nonterritoriality in the polymorphic damselfly Mnais costalis. Proc. R. Soc. Lond. (B) 267: 969-975.

Prenter J., Elwood R.W. \& Montgomery W.I. 1999: Sexual size dimorphism and reproductive investment by female spiders: a comparative analysis. Evolution 53: 1987-1994.

Raihani G., Székely T., Serrano-Meneses M.A., Pitra P. \& GoRIuP P. 2006: The influence of sexual selection and male agility on sexual size dimorphism in bustards (Otididae). Anim. Behav. 71: 833-838.

Reeve J.P. \& Fairbairn D.J. 1996: Sexual size dimorphism as a correlated response to selection on body size: an empirical test for the quantitative genetic model. Evolution 70: 1927-1938.

ReHN A.C. 2003: Phylogenetic analysis of higher-level relationships of Odonata. Syst. Entomol. 28: 181-239.

Rowe R.J. 2004: Agonistic behaviour in final-instar larvae of Episynlestes crystatus, Synlestes tropicus and Chorismagrion risi (Odonata: Synlestidae). Aust. J. Zool. 52: 169-181.

Rüppell O., Heinze J. \& Hölldobler B. 2001: Complex determination of queen body size in the queen size dimorphic and Leptothorax rugatulus (Formicidae: Hymenoptera). Heredity 87: 33-40.

SCHENK K. \& Söndgerath D. 2005: Influence of egg size differences within egg clutches on larval parameters in nine libellulid species (Odonata). Ecol. Entomol. 30: 456-463.

SelANDER R.K. 1966: Sexual dimorphism and differential niche utilization in birds. Condor 68: 113-151.

Serrano-Meneses M.A. \& Székely T. 2006: Sexual size dimorphism in seabirds: sexual selection, fecundity selection and differential niche-utilisation. Oikos 113: 385-394.

Serrano-Meneses M.A., Córdoba-Agullar A., Méndez V., LAyen S.J. \& SzÉKely T.: Sexual size dimorphism in the American Rubyspot: male body size predicts male competition and mating success. Anim. Behav. 73: 987-997.

SHINE R. 1989: Ecological causes for the evolution of sexual dimorphism: a review of the evidence. Q. Rev. Biol. 64: 419-461.

Sмiтh R.J. 1999: Statistics of sexual size dimorphism. J. Hum. Evol. 36: 423-459.

STOKS R. 1999: The effect of lamellae autotomy and sexual size dimorphism on startle-response performance in larvae of a lestid damselfly (Lestidae). J. Zool. 247: 269-273.

SzÉkely T., Lislevand T. \& Figuerola J. 2007: Sexual size dimorphism in birds. In Fairbairn D., Blanckenhorn W. \& Székely T. (eds): Sex, Size and Gender Roles. Oxford University Press, Oxford (in press).

Thom M.D., Harrington L.A. \& Macdonald D.W. 2004: Why are American mink sexually dimorphic? A role for niche separation. Oikos 105: 525-535.

Van Gossum H., Sánchez R. \& Cordero-Rivera A. 2003: Observations on rearing damselflies under laboratory conditions. Anim. Biol. 53: 37-45.

WAAGE J.K. 1973: Reproductive behaviour and its relationship to territoriality in Calopteryx maculata (Beauvois) (Odonata: Calopterygidae). Behaviour 47: 240-256.

Received August 23, 2006; revised and accepted February 26, 2007 